\title{
ASPECTS OF HEIDEGGER IN FRANCE
}

The present remarks are drawn from a work in progress that seeks to elucidate the nature and significance of the French reception of Heidegger's theory. My modest aim is to describe some aspects of Heidegger's extraordinary rise to prominence in French philosophy since the end of the Second World War. It is fair to say that in this period Heidegger has become the central "French" philosopher, the master thinker of contemporary French philosophy.

To begin with, a comparison with Kant's influence on the immediately succeeding discussion will be useful. Although there were some thinkers who were uninterested in the critical philosophy and others who opposed it, for the most part Kant's theory dominated later, postKantian German idealism. A similar situation now obtains in French philosophy that to an often unrealized extent today mainly takes shape within the horizon of Heidegger's thought.

The first thing to say is that the relation between Heidegger and French philosophy has always been unequal. Heidegger was widely read in and unusually aware of the history of philosphy. Over the last several hundred years, and to a degree that is difficult to understand outside the French discussion, Descartes has been the central figure in French philosophy. Descartes' influence is still dominant in French even now. It is, then, signigicant that in a critical discussion of Foucault's book, Histoire de la folie, Derrida states that Foucault shows, more through his monumental book than through his naive reading of Descartes, "a quel point l'acte philosophique ne pouvait plus être cartésien en son essence et en son projet, ne pouvant plus ne plus être en mémoire de cartésianisme, si être cartésien c'est, comme l'entendait sans doute Descartes luimême, vouloir être cartésien"1

${ }^{1}$ Jacques Derrida. L'écriture et la différence. (Paris: Seuil, 1967): 95. 
Yet there is little evidence of a positive influence of French philosophy in Heidegger's theory and none as concerns Descartes' position. To an almost unparalleled extent, Heidegger is an antiCartesian. Heidegger's single concern is the problem of being. He consistently represents Descartes early and late as the author of a theory representing the most developed form of a mistaken ontology arising on the basis of a turn away from the question of being. In Being and Time, his initial and most important work, he launches a detailed attack on the Cartesian theory that he later develops in other writings, above all in the important lecture "Age of the World Picture."

Nonetheless, and despite his negative reaction to French philosophy, Heidegger reached out toward French philosophy on two occasions. In a text written in 1937, "Ways to Discussion" ["Wege zur Ausprache"] after the period of his service as rector of the University of Freiburg, as Germany and Europe were moving rapidly toward the Second World War, Heidegger examines the conditions of agreement between the French and the Germans. Here he states his view of understanding among peoples in a description of the authenticity of a people as following from its realization in a future historical context before calling upon the French to do likewise. This little known text received scant attention at the time and is not even included in the edition of Heidegger's Collected Works now in preparation, although it is certainly significant for an appreciation of Heidegger's relation to French philosophy².

A decade later Heidegger addressed himself to the French in another, extremely well-known text, the "Letter on Humanism," written in 1947 in response to an inquiry from Jean Beaufret. Here he reinterpreted his early position through the concept of a turning in his thought. This concept has two functions in this text. In the first place, it serves to designate the normal evolution of his position, like any position that does not merely stagnate. Second, as a letter to the French almost immediately after the war it is meant to reassure French readers that

${ }^{2}$ For a discussion of this text, see Tom Rockmore, On Heidegger's Nazism and Philosophy. (Berkeley: University of California Press, 1992): 119-121. 
through a turning in his thought he has stirred away from his leaning toward National Socialism, including his membership in the Nazi party, his service as rector to the University of Freiburg, and so on. Like other Nazis, after the war Heidegger was called to account for his actions. On the advice of Karl Jaspers, his friend, he was rusticated from the University. Since Freiburg was in the French occupation zone, in insisting in his own way that he is a humanist, Heidegger the philosopher appeals through his text to French philosophers and, beyond them, to the French occupation authorities who temporarily drove him from the university.

Heidegger's theory was introduced into France in the late 20 s and early 30 s before his Nazi turning. It only became widely influential after the war. A major factor in the unusual receptivity of French philosophy and culture to Heidegger's theory lies in the humanist aspect that is a constant in French philosophy. We can distinguish two senses of humanism, as concerns classical studies, or studia humanitatis, and the theory of human being, what later led to the human sciences (les sciences de l'homme). Jacob Burkhardt has shown that the idea of human being was central to the Italian renaissance, for instance in Petrarch's poetry. In philosophy, the science of man is a main theme in the theories of Hume and Kant.

French thought, especially philosophy, has long centered on the conception of human being. It was present in Rabelais, in the famous letter to Pantagruel from Gargantua, his father. In philosophy, it is a factor in Montaigne's Essais that concern himself as the subject in order to emerge from scepticism. It is further developed in Descartes' theory, beginning with the Traite de Phomme, continuing in the Discours de la méthode, with its injunction, following Montaigne, to look into myself, and the famous Méditations de philosophie première that were originally to be titled "Projet d'une science universelle qui puisse élever notre nature à son plus haut degré de perfection." And it is still present in his final text, "Les passions de l'âme." The same humanist theme that is later restated in Condorcet's well known Esquisse d'un tableau historique des progrès de Pesprit humain runs throughout all later French thought. Recent examples include Roger Garaudy's attempt in Perspectives de Phomme: Existentialisme, pensée Catholique, structuralisme, marxisme (Paris: Presses Universitaire de France, 1969) and Mikel Dufrenne's 
reaffirmation of human being in Pour Phomme (Paris: Seuil, 1968).

When speaking of humanism as a theory of human being, it is natural to approach human being through some version of philosophical anthropology. If French philosophy is basically humanist, it is hardly surprising that the initial phase of the French Heidegger reception provided an interpretation of Heidegger's theory as an anthropological theory of human being. This view arose in the early discussions and translations of his thought due to Koyré, Kojève, Corbin, Gurvitch, Levinas, Wahl and others. In different ways, all of these writers were interested in Heidegger's theory from a humanist angle of vision solidly anchored in philosophical anthropology.

Kojève particularly did much to foster the early French humanist reading of Heidegger through his famous lectures in the 1930s on Hegel's Phenomenologyof Spirit later published by Raymond Queneau as Introduction à la lecture de la Phénoménologyde Pesprit de Hegel. Kojève, who argued that Hegel's theory is a philosophical anthropology whether or not he was aware of it, based his own reading of this book, on the views of Marx and Heidegger. Yet a reading of Hegel's Phenomenology as a philosophical anthropology through the lens provided by the theories of Marx and Heidegger is possible only if these theories are also philosophical anthropologies.

Kojève further influenced Corbin's influential rendering of Heidegger's term "Dasein," which literally means "existence," as "réalité humaine," a translation that Beaufret refused and Derrida later branded as "monstrous." The initial anthropological reading of Heidegger's theory as humanism reached its high point immediately after the war in Sartre's popular lecture, "L'existentialisme est un humanisme." In this difficult period when Sartre's own humanism was in question, he defended himself by saying in effect that his own view was a humanism in the same way as Heidegger's.

The initial French reading of Heidegger's theory as a traditionally anthropological form of humanism is suggested by a number of internal indications in paragrph 10 of Heidegger's Being and Time, including his criticism of traditional humanism but not humanism, his insistence that 
human being is literally in the world and not transcendent to it, and his approval of a wider theory of human being encompassing all human aspects. Yet this reading runs counter to Heidegger's own explicit effort in this same paragraph 10 to draw a clear distinction between his own theory and all the sciences of man, including biology, psychology and anthropology. If we follow Heidegger's official view and bracket his other indications, it is clearly an error to read his theory as a humanism in an anthropological sense of the term.

The reaction to Sartre's identification of existentialism with Heidegger's theory rapidly led to a new phase of the Heidegger reception in which Heidegger's position, following his "Letter on Humanism," was reinterpreted as a humanism of a different type. The new phase of the Heidegger reception followed Heidegger's text in several ways to create a new reading of Heidegger's theory as a nonanthropological humanism. In his text, Heidegger criticized Sartre's view for its uncritical reproduction of metaphysics, hence philosophy, while suggesting that his own theory was located beyond metaphysics and, for that reason, beyond philosophy. The new thinking that is to come, Heidegger insisted, lies beyond theory and practice; it is no longer philosophy.

In his text, Heidegger devotes special attention to the idea of humanism that he labels as metaphysical. His objection is directed to the very idea of human being as understood through itself. The proper approach to human being, he maintains, is in terms of being. He returns in this way to the understanding of human being (Dasein) in terms of being (Sein) first sketched in Being and Time. The resultant theory, he insists, is still a humanism, although not in the traditional sense, since human being is no longer understood in an anthropological but in a nonanthropological perspective. Heidegger's nonanthropological humanism is not metaphysical but postmetaphysical, occurring on a further remove beyond the philosophical tradition.

The new reading of Heidegger's thought as nonanthopological humanism, based on his "Letter on Humanism," agrees with the nonanthopological thrust of paragraph 10 of Being and Time where Heidegger strove to distance his own theory from the various positive sciences. This new reading is the fundamental text underlying the understanding of 
Heidegger's thought that still persists in French philosophy and that continues to form the horizon of the contemporary French philosophical discussion. This nonanthropologicalconception of the subject is doubly influential in the French philosophical context. It is, to begin with, reflected in the view of Heidegger's thought that in France has always been understood through the "Letter on Humanism" that is in large part a letter to the French. That this text has been so influential is due to a number of contingent factors, including its rapid translation into French whereas it was necessary to wait more than half a century for the first complete, but still unauthorized translation of Being and Time, and the important effort at proselytizing undertaken by Heidegger's French students, particularly Jean Beaufret.

It is further influential in the rise of French structuralism. French structuralism that emerged in the 1960s can be understood from two perspectives, as a revolt against the domination of Sartre's theory, as French thinkers sought to withdraw from the influence of a perhaps objectionable French guru, and as a turn to Heidegger's later decentering of the subject as he accentuated the nonanthropological, in fact antianthropological direction of his thought. The celebrated French structuralist turn away from human being, best known in Lévi-Strauss' structural anthropology and Foucault's idea of the death of man, is directly traceable to the nonanthropological conception of subjectivity Heidegger advances in his "Letter on Humanism" amd other later writings.

The nonanthropological, humanist reading of his theory that Heidegger presented in his letter to the French was defended by his French students, above all by Beaufret, its original recipient. When he wrote to Heidegger at the close of the war, Beaufret was merely an obscure French student of phenomenology who had become interested in Heidegger's theory that he saw to be lurking in the background of Sartre's. Heidegger's initial praise of Beaufret who had not yet made a name for himself was clearly linked to his own desire to curry favor with the French, to seize the occasion that Beaufret's letter represented for him, to utilize Beaufret in his time of need. When Beaufret later made a name for himself, it was as the unconditional defender of Heidegger's theory that he patiently explained to the French in the course of a dialogue with the master thinker extending over more than thirty years. 
The phenomenon of orthodoxy is well known in philosophy. It is illustrated by the relation of the post-Kantians to Kant, each of whom claimed to be the only one who truly understood the master's thought. It is illustrated as well by the relation of Marxists to Marx, beginning with Friedrich Engels, the first Marxist, who initially raised the claim alone to understand Marx's theory. Other thinkers, including Heidegger, have had orthodox disciples, writers who cleaved to the master's thought, who saw their only task as the authentic statement of the master's ideas. Heidegger has created numerous disciples, in Germany Friedrich-Wilhelm von Hermann and in the US William Richardson, writers who subordinate their entire professional career, in effect their professional being, entirely to the master's thought and being. But no one has ever had a more loyal, more selfeffacing, more orthodox disciple than Beaufret who ceaselessly sounded the call to Heidegger's thought as literally incomparable with anything else in the philosophical tradition, as sui generis hence as incomparable, like being itself beyond the possibility of predication.

A disciple may normally devote a couple of papers, perhaps a volume to the master's thought. Beaufret was not a normal disciple since his attachment to Heidegger's life and thought knew no limits. Beaufret himself recalls that he was once the only student in one of Heidegger's seminars $^{3}$. Over the course of his lengthy dialogue with the master, he produced no less than four volumes of dialogues with Heidegger, a couple of volumes of interviews, many papers, around a dozen radio talks, and so on, all without a single critical word. He further trained an entire generation of French Heidegger students, many of whom became well known, such as Courtine, Marion, Janicaud, and so on. None of Beaufret's students is quite as orthodox as he was and some have even become critical of Heidegger over time. Yet by his own admission, in that time only one of his students ever rejected the view of Heidegger he presented, only one of them ever rejected the authorized version of Heidegger's thought. Throughout this period, Beaufret, who had privileged access to the master's texts, and who frequently traveled to Freiburg to meet with him, was constantly able to cite unpublished

3 Se Jean Beaufret, Dialogue avec Heidegger. IV: Le chemin de Heidegger. (Paris: Minuit, 1985): 21. 
documents and personal communications to bolster the authorized version of the master's thought.

The view that Beaufret presented did not differ as much as a comma with the view that Heidegger himself offered in the "Letter on Humanism." This way of reading Heidegger as a nonanthropological humanist is still largely dominant in the French philosophical discussion. It can be illustrated by Derrida's well known article on "Les fins de l'homme $^{\text {"4 }}$ that reproduces without criticism of any kind, in the familiar orthodox style pioneered by Beaufret in France, all the main traits of Heidegger's selfindulgent reading of his theory as a nonanthropological humanism in the course of a violent attack on Sartre. Derrida's relation to Heidegger's theory is a key to an understanding of his own view. According to Derrida, although Heidegger is present in all his texts, he always preserves a critical distance from the master. Yet Derrida mainly, often tends to reformulate in his own language precisely that reading transmitted everywhere in French philosophy over many years by Beaufret's efforts.

This nonanthropologicalhumanist reading of Heidegger's theory follows directly from Heidegger's "Letter on Humanism" (and) has been highly influential in French philosophy, above all in the effort to come to grips with the problem posed by Heidegger's Nazi turning. Heidegger's rise to influence in French philosophical circles depended initially on the interpretation of his "Letter on Humanism" as indicating that his political engagement had been brought to a close, that he had later turned away from Nazism. The resurgence of Victor Farias' study, Heidegger et le nazisme, (Paris: Verdier, 1987), gave rise to a violent debate. This debate raised again the old problem of the link between Heidegger's philoso-phical thought and his political engagement, Heidegger the great philosopher and Heidegger the ordinary Nazi.

In view of Heidegger's preeminent role in French philosophy, it is difficult for French philosophers, who tend to equate an attack on Heidegger with an attack on French philosophy, to understand the

`See Jacques Derrida, Marges de la philosophie. (Paris: Minuit, 1972): 129-164. 
problem other than through the matrix of his thought. The same idea of the turning that forms the basis of the nonanthropological humanist reading of Heidegger's theory is also used to save if not the theoretician and the early theory at least the later theory. In closely related ways, both Derrida and Lacoue-Labarthe argue that although the early Heidegger was led to Nazism that is metaphysical humanism through his early theory, the later Heidegger leaves both Nazism and metaphysics behind in his turn against philosophy. This argument leads to some of the stranger statements of this or any time, as in Lacoue-Labarthe's claim that "le nazisme est un humanisme..."

This way of reading Heidegger's theory to save its later phase runs against the grain of the theory it is meant to save. The later development of Heidegger's theory, as he clearly insists, does not leave behind but only deepens its original formulation. It follows that either Heidegger's theory was and remains metaphysical, in which case we can understand that he never gives up Nazism to which he turned on the basis of a theory that only grew deeper but never broke with its original formulation; or the theory never was metaphysics, the later theory is unrelated to Nazism and the original turning to Nazism becomes incomprehensible.

This reading of Heidegger's theory that forms the main theme of the second phase of the French Heidegger reception was advanced to correct the initial misreading of the theory. Yet the second, corrected reading is itself a misreading, every bit as erroneous as the initial misreading. Heidegger suggests inconsistently that humanism is metaphysics but that his own understanding of human being through being is a nonmetaphysical humanism. Now he cannot have it both ways; he must choose between the claim that metaphysics is humanism and the incompatible claim that his own theory is nonmetaphysical, albeit a new, different kind of metaphysics, a metaphysics of being, as he initially suggested in Being and Time or, on the contrary, that his theory is beyond philosophy, and not metaphysics, but then it is not humanism. In either case, on the basis of his own view of humanism as outlined in the "Letter on Humanism," it is a misreading of his theory to understand it

' Philippe Lacoue-Labarthe. La fiction du politique. (Paris: Bourgeois, 1987): 138. 
as humanism. It further follows that the course correction in which his theory was reinterpreted, no longer as an anthropological humanism, but as a nonanthropological humanism is as mistaken as the original interpretation. To the extent that this latter reading is typical of the French Heidegger discussion, it finally follows that it is mainly based on a misreading.

Professor Rockmore teaches philosophy at Duquesne University. He is the author of numerous articles and books. Among his recent publications we note, On Heidegger's Nazism and Philosophy (University of California Press); Irrationalism. Lukäs and the Marxist View of Reason (Temple University Press); Hegel. Avant et après (Editions Criterion); and forthcoming from the University of California Press, The Dark Planet. Heidegger and French Philosophy. 